\title{
Optimasi Suhu Dan Ph Pertumbuhan Lactococus Lactic Isolat Ikan Kerapu
}

\author{
Subagiyo*, Ria Azizazh Tri Nuraeni, Wilis Ari Setyati, Adi Santoso \\ Departemen IImu Kelautan, Fakultas Perikanan dan IImu kelautan, Universitas Diponegoro \\ JI. Prof. Soedarto, SH. Kampus UNDIP Tembalang, Semarang 50275 \\ Email: subagiyo.kelautan13@gmail.com
}

\begin{abstract}
Temperature and $\mathrm{pH}$ is one of the environmental factors that influence microbial growth, so it needs to be optimized in order to obtain optimum values for cell production. The experiments were performed using the medium of ROGOSA and Sharpe (MRS). The pH value is set with the addition of $1 \mathrm{~N} \mathrm{NaOH}$ and $1 \mathrm{~N} \mathrm{HCl}$ to obtain a $\mathrm{pH}$ value of 4, 5, 6, 7, and 8 . Optimization of temperature performed by incubation at 25, 30, 35 and $40 \circ \mathrm{C}$. Bacterial growth was measured by changes in optical density at $600 \mathrm{~nm}$ wave-lengh. The results showed that the initial $\mathrm{pH}$ of 7 is the initial $\mathrm{pH}$ value which produces the most rapid growth, while the initial $\mathrm{pH} 4$ provides the slowest growth. Temperature that produces the most rapid growth is 30 and $35^{\circ} \mathrm{C}$ while the temperature $40^{\circ} \mathrm{C}$ produce the slowest growth.
\end{abstract}

Keywords : Lactococcus lactis, temperature, pH, growth

\begin{abstract}
Abstrak
Suhu dan $\mathrm{pH}$ merupakan salah satu faktor lingkungan yang berpengaruh terhadap pertumbuhan mikrobia, sehingga perlu untuk dilakukan optimasi guna mendapatkan nilainilai yang optimum untuk produksi sel. Percobaan dilakukan menggunakan medium deMan, Rogosa and Sharpe (MRS). Nilai $\mathrm{pH}$ diatur dengan penambahan $\mathrm{NaOH} 1 \mathrm{~N}$ dan HCL $1 \mathrm{~N}$ hingga diperoleh nilai $\mathrm{pH} 4,5,6,7$, dan 8.. Optimasi suhu dilakukan dengan inkubasi pada suhu $25,30,35$ dan $40 \circ \mathrm{C}$. Pertumbuhan bakteri diukur berdasarkan perubahan optical density pada panjang geliombang $600 \mathrm{~nm}$. Hasil penelitian menunjukkan bahwa pH awal 7 merupakan nilai $\mathrm{pH}$ awal yang menghasilkan pertumbuhan yang paling cepat sedangkan $\mathrm{pH}$ awal 4 memberikan pertumbuhan yang paling lambat. Suhu yang menghasilkan pertumbuhan paling cepat adalah 30 dan $35^{\circ} \mathrm{C}$ sedangkan suhu $40^{\circ} \mathrm{C}$ menghasilkan pertumbuhan yang paling lambat. Kecepatan agitasi yang menghasilkan pertumbuhan paling cepat adalah $100 \mathrm{rpm}$ dan paling lambat $150 \mathrm{rpm}$.
\end{abstract}

Kata kunci : Lactococcus lactis, suhu, pH, pertumbuhan

\section{PENDAHULUAN}

Lactococcus memiliki status "GRAS" (generally recognized as safe) sehingga tidak berbahaya untuk kesehatan manusia dan hewan (Nuryshev et al, 2016). Lactococcus adalah bakteri gram positif, mikroaerofilik, homofermentatif, tumbuh pada suhu $10 \circ \mathrm{C}$ tetapi tidak tumbuh pada suhu $45^{\circ} \mathrm{C}$, menghasilkan $\mathrm{L}(+)$ asam laktat dari glukosa. Lactococcus memiliki sel berbentuk bulat tampak secara individual, dalam pasangan atau dalam rantaian (Samaržija et al, 2001). Bakteri dari kelompok ini telah dikembangkan menjadi probiotik. Probiotik memiliki berbagai macam mekanisme kerja seperti produksi bakteriosin dan asam lemak rantai pendek, menurunkan $\mathrm{pH}$ saluran pencernaan, kompetisi nutrient dan stimulasi fungsi barrier dan immunomodulasi (Kechagia et al, 2013).

L. lactis sebagai probiotik telah dikaji oleh banyak peneliti (Monteagudo-Mera et al, 2012 ; Nuryshev et al, 2016; Gad et al, 
2016; Loh dan Ting, 2016; Nejati dan Oelschlaeger, 2016).

Kajian bioproses untuk produk sel memerlukan penentuan nilai-nilai parameter pertumbuhan diantaranya adalah suhu dan $\mathrm{pH}$. Suhu dan $\mathrm{pH}$ secara umum merupakan faktor lingkungan yang berpengaruh pada pertumbuhan bakteri. Setiap spesies bahkan strain dapat memiliki nilai suhu dan $\mathrm{pH}$ optimum yang berbeda. Penelitian mengenai suhu dan $\mathrm{pH}$ pertumbuhan telah dilaporkan oleh Adamberg et al, (2003), Zaitseva et al, (2004). Pada penelitian ini ditentukan pengaruh suhu dan $\mathrm{pH}$ terhadap pertumbuhan L. lactis isolat ikan Kerapu.

\section{MATERI DAN METODE}

\section{Media}

Media yang akan digunakan untuk produksi sel adalah medium MRS (Triptone (10.0 g/l), ekstrak khamir (5.0 g/l), Glukosa $(20.0 \mathrm{~g} / \mathrm{l}), \mathrm{K}_{2} \mathrm{HPO}_{4}(2.0 \mathrm{~g} / \mathrm{l})$, sodium acetate $(5.0 \mathrm{~g} / \mathrm{l}), \mathrm{MgSO}_{4}-7 \mathrm{H}_{2} \mathrm{O}(0.2 \mathrm{~g} / \mathrm{l}), \mathrm{MnSO}_{4}-\mathrm{H}_{2} \mathrm{O}$ $(0.05 \mathrm{~g} / \mathrm{l})$, ammonium sulfat $(2.0 \mathrm{~g} / \mathrm{l})$, Tween $80(1 \mathrm{ml} / \mathrm{l}))$.

\section{Prosedur pengukuran pertumbuhan}

Pertumbuhan bakteri ditentukan berdasarkan pengukuran OD pada $A_{600}$. Satu $\mathrm{mL}$ kultur BAL disentrifugasi untuk menghilangkan medium, kemudian dicuci dengan akuades steril dan disentrifugasi kembali untuk menghilangkan sisa medium yang masih ada, kemudian diukur OD nya pada $\mathrm{A}_{600}$.

\section{Penyiapan kultur}

Kultur bakteri probiotik yang dipreservasi di dalam larutan gliserol dan skim milk pada suhu $-80 \circ \mathrm{C}$ diaktifkan secara bertahap dengan cara memindahkannya ke suhu $-20^{\circ} \mathrm{C}$ dan suhu 5 C (suhu refrigerator. Setelah itu baru dipindahkan ke medium MRS cair dan diinkubasi pada suhu kamar selama 24 jam. Selanjutnya dilakukan sub kultur pada medium yang sama dan diinkubasi pada suhu kamar.

\section{Optimasi suhu}

Medium MRS dalam erlenmeyer diinokulasi dengan starter isolat yang memberikan OD 0,1 pada $A_{600}$. Inkubasi pada variasi suhu $25^{\circ} \mathrm{C}, 30^{\circ} \mathrm{C}, 35^{\circ} \mathrm{C}, 40^{\circ} \mathrm{C}$ selama 24 jam. Selanjutnya dilakukan pengukuran OD pada $\mathrm{A}_{600}$.

\section{Optimasi pH}

Medium MRS dalam erlenmeyer diinokulasi dengan starter isolat yang memberikan OD 0,1 pada $\mathrm{A}_{600}$. $\mathrm{pH}$ awal medium diatur pada variasi 4 , 5, 6, 7 dan 8. Inkubasi selama 24 jam Selanjutnya dilakukan pengukuran OD pada $A_{600}$.

\section{HASIL DAN PEMBAHASAN}

Suhu merupakan faktor lingkungan
yang berpengaruh terhadap laju
pertumbuhan melalui mekanisme terkait
dengan laju reaksi metabolism dan
stabilitas konformasi molekul-molekul
fungsional. $\quad$ Peningkatan suhu menyebabkan peningkatan energy kinetic rata-rata molekul reaktan sehingga menyebabkan peningkatan laju reaksi. Hal ini berlaku terhadap reaksi metabolisme. Metabolisme merupakan reaksi kimia yang terarah yang berlangsung didalam sel yang dikatalisis oleh enzim, maka reaksi enzimatik dipengaruhi oleh suhu. Suhu berpengaruh terhadap kinetika dan stabilitas molekul enzim (Thomas dan Scopes, 1998), sehingga aktivitas enzim bergantung pada suhu (Peterson et al, 2007). Menurut Daniel et al (2008) ada 2 hal terkait dengan pengaruh suhu terhadap enzim yaitu energy aktivasi dan stabilitas thermal. Pengaruh terhadap metabolisme selanjutnya akan berpengaruh pada pertumbuhan. Membre et al (2005) telah mengkaji pengaruh suhu terhadap laju pertumbuhan berbagai bakteri yaitu Listeria monocytogenes, Salmonella, Escherichia coli, Clostridium perfringens and Bacillus cereus. Suhu optimum untuk pertumbuhan bervariasi antar spesies.

Pertumbuhan L. lactis pada penelitian ini bervariasi bergantung suhu 
inkubasi. Berdasarkan hasil pengukuran (Gambar 1) tampak bahwa ke tiga isolat L.lactis menunjukkan pertumbuhan yang baik pada rentang nilai suhu $25-35 \circ \mathrm{C}$ dan menunjukkan pertumbuhan yang lambat ada suhu $40 \circ \mathrm{C}$.

Suhu optimum yang berbeda pada tingkat strain menunjukkan adanya variabilitas pada tingkat strain. Fenomena ini telah direview oleh (Lianou dan Koutsoumanis, 2013). Ahmed et al (2006) melaporkan suhu optimum untuk pertumbuhan L. lactis $37-40{ }^{\circ} \mathrm{C}$ dan Aslam et al, (2012) melaporkan $37^{\circ} \mathrm{C}$.
Nilai suhu bervariasi antar spesies ditunjukkan antara lain oleh Lactobacillus curvatus LTH 1174 memiliki suhu optimum 34.5 'C (Messens et al. 2003), Streptococcus macedonicus ACA-DC 198 $42,3 \circ \mathrm{C}$ (Van den Berghe et al (2006)). Variasi intraspesies ditunjukkan oleh laporan Calderón-Santoyo et al (2001) bahwa Pediococcus acidilactici ITV 126 memiliki suhu optimum untuk pertubuhannya $40{ }^{\circ} \mathrm{C}$., sedangkan Zhang et al (2012) melaporkan bahwa suhu optimum untuk pertubuhan $P$. acidilactici PA003 adalah $35^{\circ} \mathrm{C}$.

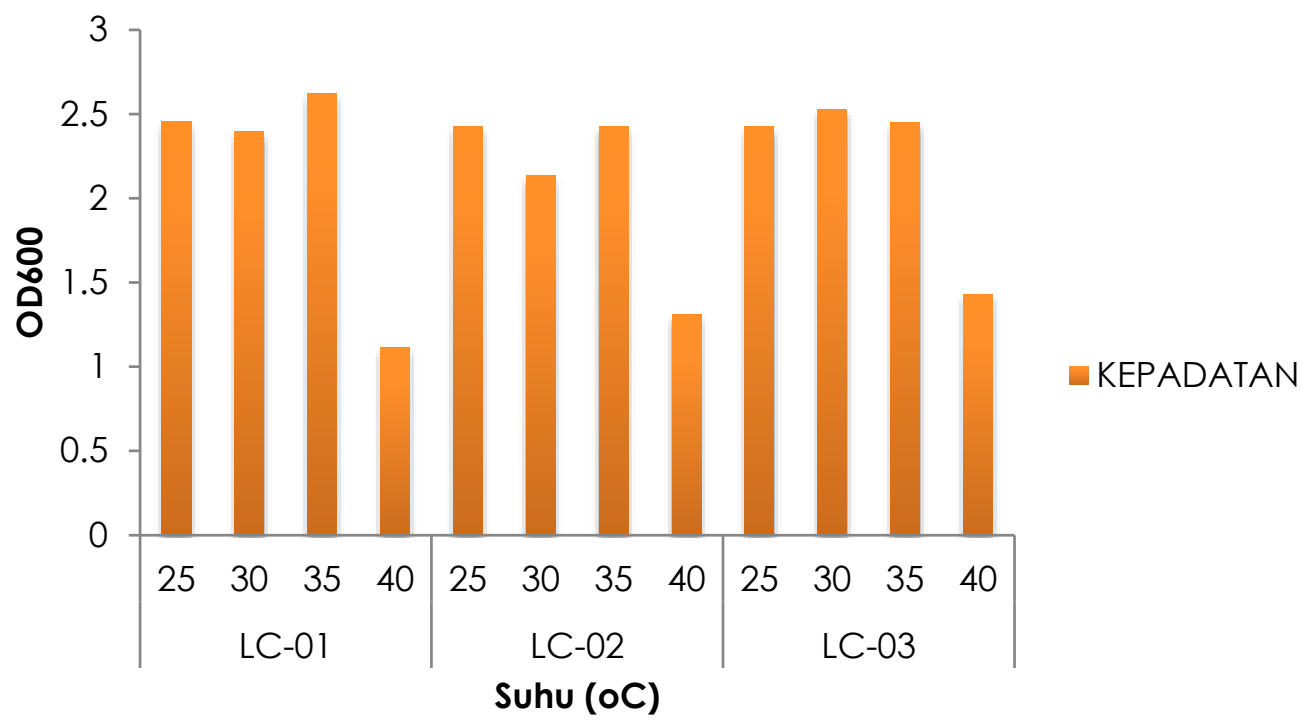

Gambar 1. Pertumbuhan L.lactis pada berbagai nilai suhu

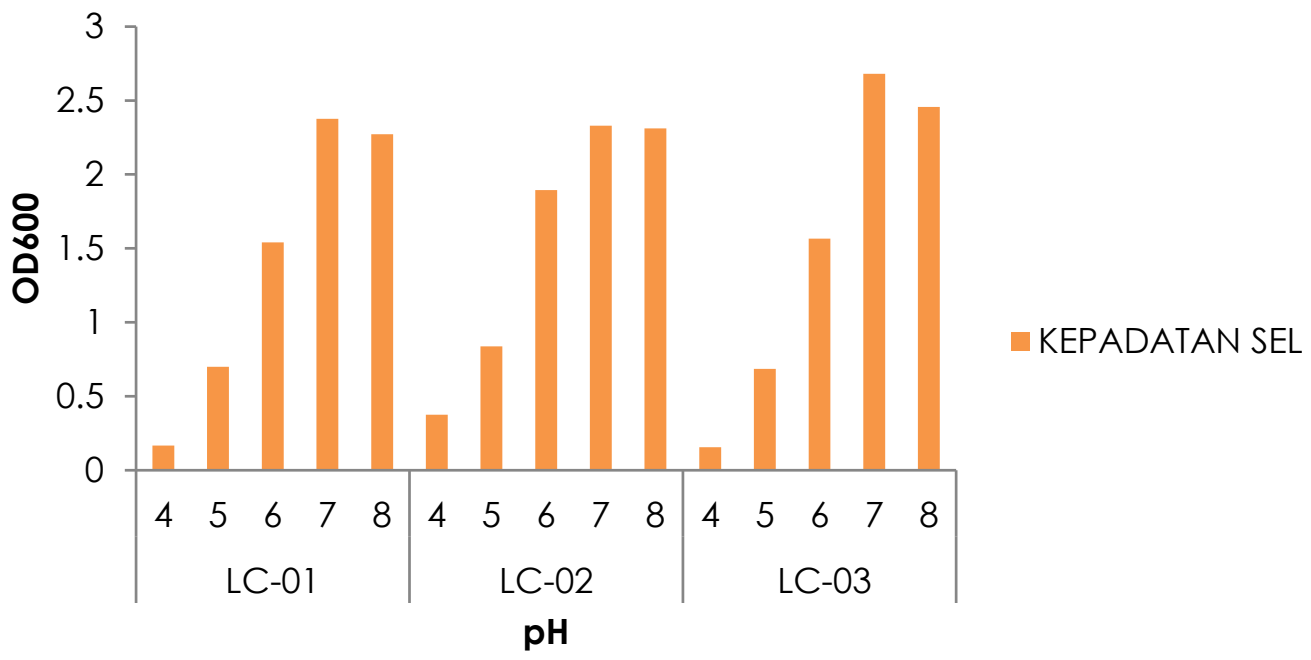

Gambar 2. Pertumbuhan L. lactis pada berbagai nilai $\mathrm{pH}$ 
$\mathrm{pH}$ berpengaruh terhadap pertumbuhan melalui pengaruhnya terhadap derajat ionisasi asam amino basa dan asam. Jika derajat ionisasi asam amino dalam protein berubah maka ikatan ion yang ikut menentukan struktur 3 dimensi protein juga akan berubah. Perubahan struktur protein ini dapat menyebabkan gangguan fungsionalnya. Perubahan pada protein enzim akan menyebabkan perubahan pada pengenalan protein atau inaktivasi enzim. Perubahan ph tidak hanya menyebabkan perubahan bentuk enzim tetapi juga menyebabkan perubahan bentuk dan sifat muatan dari substrat. Sehingga substrat tidak dapat berikatan dengan bagian aktif enzim atau tidak dapat dikatalisis.

Hasil pengukuran pertumbuhan pada berbagai nilai pH awal (Gambar 2) menunjukkan bahwa $L$. lactic tumbuh baik pada nilai $\mathrm{pH}$ awal 7-8, pertumbuhan yang lambat terjadi pada ph asam (4 dan 5). Hasil yang sama ditunjukkan oleh Lactococcus piscium CNCM I-4031 yang memiliki pH optimum pada nilai netral (Leroi et al, 2012). Hal ini berbeda dengan pernyataan O'sullivan dan Condon, (1997) bahwa pH optimal untuk pertumbuhan Lactococcus 6.3- 6 , dan Hofvendahl et al, (1999) melaporkan $\mathrm{pH}$ optimum untuk lactococci dan lactobacilli berada di sekitar nilai 6 , sedangan Aslam et al, ( 2012) pH optimum pertumbuhan L. lactis adalah 5.0.

\section{KESIMPULAN}

Berdasarkan pertumbuhan (perubah-an optical density /OD600) selama 24 jam menunjukkan L. lactic isolat ikan kerapu tumbuh baik pada rentang nilai suhu $25-35^{\circ} \mathrm{C}$ dan nilai $\mathrm{pH}$ awal 7-8.

\section{UCAPAN TERIMAKASIH}

Penelitian ini Dibiayai dengan sumber dana PNBP DIPA Universitas Diponegoro Nomor : SP DIPA 042.01.2.400898/2016, tanggal 7 Desember 2015, Tahun Anggaran 2016

\section{DAFTAR PUSTAKA}

Alexandra Lianou, Konstantinos P. Koutsoumanis, 2013,Strain variability of the behavior of foodborne bacterial pathogens:A review, Int. J. Food Microbiol., 167: 310-321

Ademberg K, Kask S, Laht TM, Paalme T (2003). The effect of temperature and $\mathrm{pH}$ on the growth of lactic acid bacteria: a $\mathrm{pH}$-auxostat study. Int. J. Food Microbiol. 85: 171-183.

Ahmed T, Kanwal R, Ayub $N$ (2006). Influence of temperature on growth pattern of Lactococcus lactis, Streptococcus cremoris and Lactobacillus acidophilus isolated from camel milk. Biotechnology, 5(4): 481-486.

Hofvendahl K, Van Niel EWJ, HahnHagerdal B (1999). Effect of temperature and $\mathrm{pH}$ on growth and product formation of Lactococcus lactis spp. lactisATCC 19435 growing on maltose. Appl. Micobiol. Biotechnol. 51: 669-672.

Kim WS, Ren J, Dunn NW (2001). Assessment of the tolerance of Lactococcus lactiscells at elevated temperatures. Biotechnol. Lett. 23: 1141-1145.

O'sullivan ,E., S. Condon, 1997, Intracellular $\mathrm{Ph}$ Is A Major Factor In The Induction Of Tolerance To Acid And Other Stresses In Lactococcus Lactis, Appl. Environ. Microbiol., 63:4210-4215

Booth, I. R., 1985, Regulation Of Cytoplasmic $\mathrm{pH}$ In Bacteria, Microbiological Reviews, 49: 359-378.

Jeanne-Marie Membré, J,M., B. Leporq, M. Vialette, E. Mettler, L. Perrier, D. Thuault, M. Zwietering, 2005, Temperature effect on bacterial growth rate: quantitative microbiology approach including cardinal values and variability estimates to perform growth simulations on/in food, Int. J. Food Microbiol. 100:179-186

Thomas, M.T., K. R. Scopes, 1998, The Effects Of Temperature On The Kinetics And Stability of Mesophilic And Thermophilic 3-Phosphoglycerate Kinases, Biochem. J. 330 : 1087-1095 
Peterson, M.E., R. M. Daniel, M. J. Danson, R. Eisenthal, 2007, The dependence of enzyme activity on temperature: determination and validation of parameters, Biochem. J. $402: 331-337$

Leroi, F., P. A. Fall, M. F. Pilet, F. Chevalier, R. Baron, 2012, Influence of temperature, $\mathrm{pH}$ and $\mathrm{NaCl}$ concentration on the maximal growth rate of Brochothrix thermosphacta and a bioprotective bacteria Lactococcus piscium CNCM 1-4031, Food Microbiology, 31: 222-228

Nuryshev, M. Z., L. G Stoyanova and A. I. Netrusov, 2016, New Probiotic Culture of Lactococcus lactis ssp. lactis: Effective Opportunities and Prospects, J Microb Biochem Technol, Volume 8(4): 290-295 (2016) - 290

Gad,S.A., R. M. A. E-Baky, A. B. F. Ahmed and G. F. M. Gad, 2016, In vitro evaluation of probiotic potential of five lactic acid bacteria and their antimicrobial activity against some enteric and food-borne pathogens, African J. Microbiol. Res. 10:400-409

Monteagudo-Meraa, A., L. Rodri'guezAparicioa, J. Ru' aa, H. Martı́nezBlancoa, N. Navasaa, M. R. Garci'aArmestob, M. A'. Ferrero, 2012, In vitro evaluation of physiological probiotic properties of different lactic acid bacteria strains of dairy and human origin, J. Funtional Foods. 4: 531-541

Loh, J.Y.,A.S.Y. Ting, 2016, Effects of potential probiotic Lactococcus lactis subsp. lactis on digestive enzymatic activities of live feed Artemia franciscana, Aquacult. Int. 24: 13411351.

Nejati, F., T. A. Oelschlaeger, 2016, In Vitro characterization of Lactococcus lactis strains Isolated from Iranian Traditional Dairy Products as a Potential Probiotic , Appl. Food Biotechnol. 3 : 43-51

Zaitseva, S.V., Kozyreva, L.P. \& Namsaraev, 2004, The Effect of Temperature and $\mathrm{pH}$ on the Growth of Aerobic Alkalithermophilic Bacteria from Hot Springs in Buryatia, B.B Microbiol.73: 372.

Adamberg K, Kask S, Laht TM, Paalme T. 2003, The effect of temperature and $\mathrm{pH}$ on the growth of lactic acid bacteria: a pH-auxostat study, Int J Food Microbiol. 85:171-183.

Samaržija, ., N. Antunac, J. Luka_ Havranek, 2001, Taxonomy, physiology and growth of Lactococcus lactis: a review, Mljekarstvo 51:35-48, 